Agnieszka Bojarska-Sokotowska

ORCID: 0000-0003-3864-2263

Uniwersytet Warmińsko-Mazurski w Olsztynie

bojarska@matman.uwm.edu.pl

\title{
Wykorzystanie STEAM-owego projektu w kształtowaniu wybranych pojęć geometrycznych u przedszkolaków
}

\begin{abstract}
Summary
The use of STEAM project in shaping selected geometric concepts in preschoolers

The article presents the concept of using steam design in the shaping of geometric concepts in preschool children. Attention was paid to shaping the spatial imagination of children, i. e. developing spatial orientation, discovering the properties of solids and the concept of symmetry. However, mathematical knowledge was not treated as a separate field of knowledge, but as a tool to solve a specific problem, which in this study is the creation of a tourist, mobile guide.
\end{abstract}

Keywords: STEAM, geometric intuitions of children, spatial orientation

Słowa kluczowe: STEAM, intuicje geometryczne dzieci, orientacja przestrzenna

\section{Wstęp}

Geometria towarzyszyła człowiekowi od zawsze. Początkowo nie jako teoria naukowa, lecz jako koncepcja rozwiązywania konkretnych problemów, które pojawiały się m.in. w trakcie zagospodarowywania przestrzeni: w budownictwie, zdobnictwie, wykonywaniu niezbędnych narzędzi, podczas podróżowania czy tworzenia muzyki, sztuki itp. Historyczny rys rozwoju matematyki wskazuje drogę dla dydaktycznego podejścia do geometrii szkolnej, ta wiedza powinna się rodzić przez działanie, tj. zdobywanie doświadczenia, manipulacje i praktyczne rozwiązywanie problemów (Pytlak 2014: 106). Zbigniew Semadeni przekonuje, że rozwój pojęć geometrycznych u dziecka opiera się na percepcji (wzrokowej, dotykowej), co może potwierdzać fakt, że terminy geometryczne pochodzą najczęściej od rzeczowników oznaczających konkretne obiekty, których kształt kojarzył się człowiekowi z daną figurą, np. ,słowo linia pochodzi od lnianej nici (...) punkt pochodzi od ukłucia (...), średnica pochodzi od środka, (...) oś pochodzi od ość, wierzchołek od wierzch, stożek od stóg (...)" (Semadeni i in. 2015: 19). Współcześnie geometria jest „,naturalnym i prawdopodobnie niemożliwym do zastąpienia łącznikiem między zwykłym językiem a sformalizowanym żargonem matematycznym” (za: Tocki 2006: 100). 
W polskiej podstawie programowej dla przedszkoli niewiele miejsca poświęca się na realizację zagadnień dotyczących geometrii. Dotyczą one szczególnie: twórczej czynności konstruktorskiej dziecka; zagospodarowywania przestrzeni; określania położenia, liczby i wielkości przedmiotów; porównywania przedmiotów w otoczeniu dziecka ze względu na wybraną cechę; klasyfikację przedmiotów według kształtu i wielkości; układanie przedmiotów w grupy, szeregi i odtwarzanie układów przedmiotów; rozróżnianie podstawowych figur geometrycznych, takich jak: koło, kwadrat, trójkąt, prostokąt; określanie kierunku i ustalanie położenia przedmiotów w stosunku do własnej osoby i w stosunku do innych przedmiotów; rozróżnianie lewej i prawej strony; zagospodarowywanie przestrzeni własnymi pomysłami konstrukcyjnymi (Rozporządzenie Ministra Edukacji Narodowej z dnia 14 lutego 2017 r. w sprawie podstawy programowej wychowania przedszkolnego oraz podstawy programowej kształcenia ogólnego dla szkoły podstawowej... Dz. U. z 2017 r., poz. 356, ze zm.: 6-7). Jak zauważają Monika Czajkowska i Beata Bugajska-Jaszczołt, nauczanie geometrii małego dziecka (edukacja przedszkolna i wczesnoszkolna) ,(...) skupione jest na treściach z planimetrii, natomiast treści z geometrii przestrzennej pojawiają się jedynie w kontekście liczenia lub figur płaskich. Pomimo, że uczniowie posługują się modelami brył, to nie poznają terminów ze stereometrii. Przykładowo przyglądają się pudełku (a nie prostopadłościanowi), czy kostce (a nie sześcianowi), rozpoznają kształty ścian tych przedmiotów" (Czajkowska, Bugajska-Jaszczołt 2018: 21). Mimo że autorzy podstawy programowej uwzględnili na poziomie edukacji wczesnoszkolnej organizację pracy z dziećmi w formie: zabawy; wykonywania eksperymentów naukowych; eksploracji, przeprowadzania badań konstrukcyjnych (Rozporządzenie Ministra Edukacji Narodowej 2017: 17), większość nauczycieli stosuje w edukacji matematycznej przede wszystkim wypełnianie kart pracy, czyli tzw. „papierową matematykę”. Potwierdzają to w swoich badaniach m.in. Czajkowska i Bugajska-Jaszczołt (2018: 25). W trakcie tak prowadzonych zajęć uczniowie nie obserwują, nie eksperymentują, nie badają własności kształtów, np. brył, nie stawiają pytań i nie wyciągają samodzielnie wniosków (Gruszczyk-Kolczyńska 2016: 12). Prowadzona w taki sposób edukacja geometryczna nie ukierunkowuje uczniów na budowanie pojęć obiektów geometrycznych, lecz na zapamiętywanie nazw i dokonywanie standardowych obliczeń dotyczących, w klasach młodszych, obwodów podstawowych wielokątów, a w starszych - pól czy objętości. Zadania z matematyki dotyczące treści geometrycznych proponowanie w podręcznikach/zeszytach ćwiczeń z matematyki mają w większości charakter odtwórczy i są ukierunkowane na kształcenie umiejętności arytmetycznych czy algebraicznych (przekształcanie wzorów) dzieci. Kształtowanie pojęć geometrycznych jest długotrwałym procesem. Dzieci powinny już w przedszkolu, w wyniku osobistych doświadczeń, tworzyć pewne intuicje dotyczące tych pojęć (Czajkowska i Bugajska-Jaszczołt 2018: 50). Według Jerzego Tockiego (2006: 100) kształcenie u uczniów intuicji i wyobraźni tworzy warunki sprzyjające kompleksowemu odtwarzaniu, wytwarzaniu, przekształcaniu i posługiwaniu się obrazami pojęć, niezależnie od ich formalnych definicji. W początkowych etapach edukacji koncentrujemy się na kształceniu wyobraźni przestrzennej, czyli na geometrycznym modelowaniu rzeczywistości - analizowaniu obiektów 
i stosunków realnych za pomocą pojęć geometrycznych (Tocki 2006: 101). Umiejętność „patrzenia” na pojęcia matematyczne wyrabia się przez manipulowanie konkretami oraz wykonywanie doświadczeń/eksperymentów. Już przecież Jan Amos Komeński w Wielkiej Dydaktyce podkreślał, że: „nie ma niczego w umyśle, czego by nie było w zmyśle” (1956: 186). Jeżeli będziemy tylko opowiadać dziecku o danym obiekcie geometrycznym i opisywać jego własności, to nawet kwadrat będzie dla niego trudny do wyobrażenia. Zwrócili na to uwagę Dieke van Hiele-Geldof i Pierre van Hiele (za: Semadeni 2018), którzy swoją teorię dotyczącą poziomów myślenia budowali na podstawie obserwacji gimnazjalistów. Młodzież miała trudności m.in. z rozumieniem pojęć geometrycznych, wynikające z instrumentalnego sposobu uczenia tych pojęć. Uczniowie nie mieli możliwości opanowywania kolejnych poziomów rozumowania geometrycznego. W procesie kształcenia zabrakło aktywności na poziomie najniższym - wzrokowym, na którym kształty rozpoznaje się przez spostrzeganie, np. „To jest kwadrat, ponieważ ja widzę, że to jest kwadrat” (van Hiele 2003: 186). Zabrakło też aktywności na poziomie wyższym - deskryptywnym, na którym kształty rozpoznaje się na podstawie ich własności, np.: „To jest trójkąt równoramienny, ponieważ ma trzy boki i dwa z nich są równe" (van Hiele 2003: 186). Do podobnych wniosków doszedł Milan Hejny, który pierwszy poziom w rozwoju pojęć geometrycznych scharakteryzował w następujący sposób: ,świat geometrii jest ukryty w świecie realnym. Krok za krokiem wynurza się z niego za pomocą narzędzi, które nazywamy intuicją geometryczną" (Hejny 1997: 21). Według autora na poziomie przedpojęciowym dziecko: rozpoznaje specjalną klasę własności, którymi są m.in. kształty; dobrze zna opisujące kształty słowa, typu kwadrat, koło itp.; wiąże każdy kształt ze zbiorem obiektów ze świata realnego; żaden z kształtów nie jest traktowany jako indywiduum „kwadrat jest własnością-atrybutem okna" (Hejny 1997: 21).

\section{STEAM-owy sposób uczenia się}

Geometria jako nauka abstrakcyjna jest z reguły mniej atrakcyjna dla osób uczących się, dlatego warto integrować ją z innymi dziedzinami nauki. „Świat stanowi spójną całość, tak samo jak spójną całość stanowi edukacja. Nikt z nas, patrząc na drzewo, nie mówi: »to drzewo, więc to nauka« lub »niebo jest niebieskie, więc to sztuka«. Postrzegamy $\mathrm{i}$ interpretujemy świat holistycznie, również $\mathrm{w}$ taki sam sposób radzimy sobie $\mathrm{z}$ rozwiązaniem wszelkich zadań i wyzwań, jakie niesie nam życie (...)" (Plebańska 2018: 7). Takim holistycznym rozwiązaniem w nauczaniu może być STEAM. „Edukacja STEAM integruje wiedzę z różnych dziedzin nauki, a realizowane projekty zakładają samodzielne lub zespołowe poszukiwanie przez uczniów konkretnych informacji w wybranym obszarze z wykorzystaniem różnych źródeł wiedzy oraz poszukiwanie praktycznych sposobów zastosowania wiedzy pozyskanej na drodze badawczej (...)" (Trojańska 2018: 8). Koncepcja STEAM polega na połączeniu pięciu dziedzin wiedzy: przyrody, technologii, inżynierii, sztuki i matematyki. Filozofia tej koncepcji nauczania-uczenia się jest nastę- 
pująca: ,STEAM = Science \& Technology interpretowane przez Engineering \& the Arts, bazujące na Mathematics" (Plebańska, Trojańska 2018: 9). Według Marleny Plebańskiej w STEAM-owym uczeniu należy, oprócz uwzględnienia równoległej edukacji w pięciu blokach tematycznych, kierować się następującymi wskazówkami: „im więcej zmysłów uczniowie zaangażują w edukację, tym więcej zapamiętają, tym więcej się nauczą”; „dzieci mają wyszukiwać w świecie rzeczywistym realne problemy i znajdować rozwiązania"; „dzieci samodzielnie projektują sposób rozwiązania problemu”; „dzieci przejmują kontrolę nad uczeniem się, nauczyciel przyjmuje rolę wspierającą" (Plebańska 2018: 7). Ponadto w nauczaniu STEAM-owym uwzględnia się metodę twórczej pracy projektowej, $\mathrm{tj}$. design thinking. Do głównych założeń tej metody należą: koncentracja na użytkowniku, interdyscyplinarny zespół, eksperymentowanie i częste testowanie hipotez. Budując interdyscyplinarny zespół, „dajemy dzieciom możliwość stworzenia zespołu, w skład którego wejdą uczniowie o różnych kompetencjach, różnych talentach i różnorodnych zainteresowaniach. W takim zespole uczniowie będą w stanie przeanalizować problem projektowy wszechstronnie i wielopłaszczyznowo" (Plebańska, Trojańska 2018: 44).

\section{Podstawy metodologiczne badań własnych}

Przedstawione w tym artykule obserwacje są częścią badań, które miały na celu diagnozowanie intuicji geometrycznych dzieci przedszkolnych i szkolnych z klas I-III podczas zajęć zorganizowanych w formie projektu STEAM-owego. Intuicje geometryczne rozumiane są jako „łatwość dostrzegania pewnych cech wspólnych obiektów realnych i zależności występujących między tymi obiektami, tworzenia ich myślowych reprezentacji oraz posługiwania się nimi” (Czajkowska, Bugajska-Jaszczołt 2018: 20). W artykule przedstawiono obserwację dzieci przedszkolnych podczas aktywności dotyczących: parkietaży, symetrii, odkrywania własności brył, pomniejszania figur oraz orientacji przestrzennej.

Pierwsze z zagadnień dotyczyło wypełniania figurami geometrycznymi płaszczyzny (kartki papieru), istotne tutaj są rytm i regularność geometryczna (Swoboda 2006: 132134). W parkietażu rytmicznie powtarzają się pewne motywy, co tworzy okazję do stawiania pytań i dokonywania pewnych rozumowań. Do regularności, które występują w parkietażach, można zaliczyć: przesunięcie motywu w sytuacji jednowymiarowej (wzdłuż linii) lub dwuwymiarowej (w dwóch kierunkach, prostopadłych lub nie) (Semadeni i in. 2015: 124), symetrię osiową (lustrzaną), obrót oraz translację (przesunięcie) z poślizgiem.

Zagadnienie symetrii można rozpatrywać dwojako. Po pierwsze można powiedzieć, że jakaś figura/obrazek itp. jest symetryczny, po drugie można uznać, że symetria oznacza przekształcenie geometryczne, tj. przyporządkowanie każdemu punktowi figury jej symetrycznego obrazu/odbicia. Pierwszą kwestię można zaobserwować podczas aktywności dzieci polegającej na sprawdzaniu i argumentowaniu racji, np. czy budowle na fotografiach w książkach/przewodnikach turystycznych, na zdjęciach, na obiektach rzeczywistych są symetryczne. Drugą - podczas aktywności, która może polegać np. na tworzeniu 
symetrycznych figur na siatce kwadratowej według podanego kodu albo na tworzeniu kodów przez dzieci w taki sposób, aby powstała figura była symetryczna względem jednej lub dwóch narysowanych na planszy osi symetrii (Semadeni i in. 2015: 123-124).

Trzecie zagadnienie dotyczyło brył, czyli obiektów przestrzennych. Według Bogdana Noweckiego (1988: 240-244) bardzo ważne jest, aby dzieci już w przedszkolu zapoznawały się z własnościami modeli geometrycznych, które znają z własnego otoczenia. Barbara Bilewicz-Kuźnia zwraca uwagę, że: „brak działań o charakterze geometrycznym, np. manipulowania kształtami, wyróżnienia ich w przedmiotach otaczającego świata, posługiwania się schematem czy ustalenia liczby ścian lub boków, utrudnia osiągnięcie przez dziecko wyższego poziomu rozwojowego, np. poziomu opisowego pojęcia geometrycznego, co tym samym wydłuża lub uniemożliwia budowanie się w umyśle pojęcia geometrycznego itp.” (2014: 164). Jan Filip i Tadeusz Rams dodają, że: „nauczanie początkowe geometrii winno wiązać się z bryłami, które są bliskie dzieciom i lepiej wyobrażalne niż niektóre figury płaskie. Należy pamiętać, że dziecko ma wrodzoną zdolność widzenia trójwymiarowego. Powinno być więc zapoznawane od wczesnego okresu życia z różnymi figurami przestrzeni trójwymiarowej, a zatem z tworami jedno, dwu i trójwymiarowymi. Uczeń lepiej rozumie geometrię wtedy, gdy widzi różne konfiguracje" (2000: 151). Kształtowanie się umiejętności dotyczącej określania własności brył dokonuje się przez przejście na wyższy poziom abstrakcji rozwoju pojęć geometrycznych (Hejny 1997: 23). Według cytowanego autora jest to poziom dostępny dzieciom w wieku około 10 lat i wymaga uniwersalności obiektów geometrycznych. Poziom obiektów uosobionych można scharakteryzować przy użyciu siedmiu kryteriów. Jednym z nich jest znajomość niektórych widocznych atendentów (np. dla bryły: wierzchołki, krawędzie, ściany) i niewidocznych (np. siatki, rzuty) (Hejny 1997: 23). Proponowanie zagadnień tego typu młodszym dzieciom ma na celu zdiagnozowanie, na jakim poziomie rozwoju pojęć geometrycznych się one znajdują (Bruner 1978: 379). Dorosły może obserwować wykorzystywanie własności brył przez dzieci podczas badania: kształtów brył - wyszukiwanie brył, które spełniają dane własności; układania brył z danych elementów klocków; obliczania wierzchołków, ścian, krawędzi w bryłach; budowania siatek sześcianów - kostek z klocków; rzutowania brył na płaszczyznę - układanie budowli z klocków na podstawie jednego/dwóch/trzech rzutów; dopasowywanie śladu-rzutu do bryły itp. (Bojarska-Sokołowska 2019: 196-200).

Czwarte zagadnienie obejmowało umiejętności pomniejszenia figur. Wzięto pod uwagę tylko pierwszy z zaproponowanych przez Tockiego poziom, tj. przyswojenie. Badacz ten uważa, że podczas rysowania/przedstawiania figur na tym poziomie dokonuje się przejście typu „obiekt realny lub figura abstrakcyjna $\rightarrow$ rysunek” (Tocki 2006: 175). Według Jerome'a Brunera tworzona jest wtedy lokalnie homomorficzna reprezentacja wyobrażeniowo-ikoniczna postrzeganego przedmiotu. Ma ona charakter opisowy u dzieci w wieku od 6-7 do 14-15 lat. Pomniejszanie figur jest związane z rysowaniem figur podobnych. Poglądowo można to wyjaśnić dzieciom jako rysowanie lub konstruowanie „na oko" figur mniejszych/większych od tych, które stanowią punkt odniesienia. 
Ostatnie zagadnienie dotyczyło kształtowania się orientacji przestrzennej. Edyta Gruszczyk-Kolczyńska wymienia trzy kamienie milowe w dziecięcym poznawaniu przestrzeni. Pierwszym z nich jest świadomość własnego ciała i wytyczanie kierunków w przestrzeni od osi ciała oraz ustalanie położenia różnych obiektów względem siebie, z uwzględnianiem tego, co jest po lewej lub prawej stronie ciała (Gruszczyk-Kolczyńska i in. 2015: 26). Kolejny krok milowy „pojawia się, gdy dziecko zaczyna wytyczać kierunki od obranych obiektów i ustala położenie innych obiektów względem obranego" (Gruszczyk-Kolczyńska $\mathrm{i}$ in. 2015: 27). Ostatnim kamieniem milowym jest „umiejętność przedstawienia na kartce papieru tego, co występuje w przestrzeni” (Gruszczyk-Kolczyńska i in. 2015: 27). Wymienione umiejętności mogą się kształtować poprzez następujące aktywności dzieci:

- wcielanie się dzieci w robota poruszającego się tam i z powrotem po makiecie miasta i opowiadanie, co znajduje się po prawej/lewie stronie ozobota, który mija zakamarki miasta;

- formułowanie przez dzieci wypowiedzi, które mogą dotyczyć np. konkretnych elementów makiety, czyli stwierdzenia typu „po prawej stronie kościoła znajduje się boisko" itp.;

- programowanie drogi przejazdu ozobota (dzieci muszą wybrać odpowiednie kody, jeśli chcą, żeby robot poruszał się po wytyczonym wcześniej szlaku na makiecie).

Na podstawie literatury dotyczącej kształtowania się intuicji geometrycznych u dzieci, własnych wieloletnich doświadczeń związanych z prowadzeniem zajęć z dziećmi w wieku przedszkolnym na Uniwersytecie Dzieci (Bojarska-Sokołowska 2015) oraz zajęć popularyzujących matematykę wśród dzieci i młodzieży (Bojarska-Sokołowska 2019) sformułowano następujące pytania badawcze:

1. W jaki sposób dzieci potrafią „zagospodarować” (rozumiane jako ekonomiczne wypełnienie całej płaszczyzny, z uwzględnieniem walorów artystycznych) ,przestrzeń kartki"?

2. W jaki sposób dzieci radzą sobie z badaniem symetrii?

3. Czy dzieci będą umiały policzyć i opisać elementy budowy brył, tj. wierzchołek, ściana, krawędź?

4. Czy dzieci wykażą się umiejętnością znalezienia siatki, rzutu bryły?

5. W jaki sposób dzieci odwzorują realne budowle na makietę (pomniejszanie elementów przestrzennych)?

6. W jaki sposób dzieci zaprogramują drogę robota?

W postępowaniu badawczym zastosowano obserwację uczestniczącą, która polegała na obserwacji reakcji i działań dzieci na propozycje metodyczne i stawiane im problemy. Analizowano gotowe prace dzieci oraz dokumentację fotograficzną z przeprowadzonych zajęć. Wzięto również pod uwagę wypowiedzi nauczycielek z przedszkola i studentów matematyki-animatorów, którzy podczas zajęć zorganizowanych na uczelni w formie stanowisk pomagali dzieciom: formułowali pytania badawcze, wyjaśniali (pokazywali na modelach, opowiadali o zagadnieniu) i odpowiadali na pytania dzieci. 


\section{Organizacja badań}

Od 22 maja do 19 czerwca 2019 r. w Niepublicznym Przedszkolu „Krasnal” w Olsztynie przeprowadzono projekt pt. „Ozobotyczny przewodnik turystyczny po mieście”. Uczestniczyło w nim 27 dzieci w wieku 5-7 lat (jedno dziecko miało 5 lat, 13 dzieci - 6 lat, pozostałe dzieci miały 7 lat). Dzieci podzielono na trzy zespoły, w których miały projektować swoje wymarzone miasto, a następnie przemyśleć i przedstawić przejazd robota, którego zadaniem było informowanie o zabytkach, atrakcjach i szczególnych miejscach miasta. Do elementów projektu należały następujące aktywności:

- spacer po mieście, którego trasa była następująca: przedszkole - informacja turystyczna - stare miasto - most nad Łyną - mury zamku - przedszkole;

- wypożyczenie, przeglądanie i czytanie książek o miastach: zabytkach, komunikacji, parkach itp. i dyskutowanie na ich temat;

- wycieczka do parku, obserwacja przez dzieci elementów krajobrazu, tj. ławek, chodników, placów zabaw, placów treningowych itp.;

- wykonanie makiet miast, układanie informacji turystycznych, które wypowiadał poruszający się robot.

Podczas zajęć matematycznych, do których należały: zabawy z symetrią; odkrywanie własności parkietaży; zabawy z bryłami; wykonywanie elementów makiety; programowanie ozobotów, prowadzono dodatkowo obserwację reakcji i działań dzieci. Zabawy z symetrią polegały na:

- wykonywaniu eksperymentów dotyczących symetrii lustrzanej, polegających na przekonaniu się, czy coś jest symetryczne czy nie;

- odkrywaniu przez dzieci własności symetrii, tj. że jest oś/osie symetrii, że w lustrze strony się zmieniają, tzn. strona lewa jest po prawej;

- klasyfikowanie budowli mijanych podczas spaceru i przedstawionych na zdjęciach na obiekty symetryczne i niesymetryczne, z odpowiednią argumentacją. Gdy budynek był symetryczny, przedszkolaki wskazywały co najmniej jedną oś symetrii. Gdy budynek nie był symetryczny, wskazywały element, który burzył tę symetrię.

Na zajęciach dotyczących planimetrii dzieci odkrywały własności parkietaży, tzn. jakimi figurami (z dostępnych dzieciom wielokątów) można zapełnić kartkę papieru bez szczelin, w jaki sposób układać figury, aby kartka była całkowicie wypełniona. Układanie markietaży platońskich typu: $(3,3,3,3,3,3),(4,4,4,4),(6,6,6)$ oraz archimedesowskich typu: $(3,6,3,6),(3,3,3,3,6),(3,3,3,4,4),(3,4,3,3,4)$ według zadanego kodu, ćwiczenie rytmów. Podczas zajęć dotyczących brył dzieci miały okazję do: manipulacji bryłami przestrzennymi, poznania i obliczenia ich elementów, tj. krawędzi, wierzchołków i ścian. Odgadywały, wskazywały i układały zagadki dotyczące brył. Wykonywały eksperyment polegający na rozcięciu prostopadłościennego pudełka, tak aby można go było „płasko” rozłożyć na ławce, składały kostki z klocków Rekosiatek. Układały budowle z klocków na podstawie ich trzech rzutów: $\mathrm{z}$ dołu, z boku i z tyłu. 
Podczas zajęć dotyczących programowania ozobotów dzieci poznawały kody umożliwiające poruszanie się robotów, np.: prędkości (wolno, szybko, turbo itp.), kierunku (skręt w lewo, prosto, przeskok w prawo itp.), czasu (np. przerwa 3 sekundy itp.) oraz specjalne możliwości poruszania się (zygzak, tornado itp.). Dzieci planowały trasy poruszania się ozobota na swoich makietach, wykonując ćwiczenia typu: coś znajduje się po lewej, po prawej stronnie poruszającego się robota itp.

Zaproponowany dzieciom projekt został zbudowany na zasadach STEAM-owych lekcji, dlatego też uwzględniono w nim wszystkie elementy STEAM. W obszarze Science dzieci poznawały nazwy drzew, krzewów, kwiatów i zwierząt, które można spotkać w parkach miejskich. Lepiły z plasteliny lub budowały z papieru i bibuły ich odpowiedniki, które były umieszczane na makiecie. W obszarze Technology przedszkolaki uczyły się obsługi ozobotów, programowania robotów. Dzieci stworzyły mobilny przewodnik turystyczny po mieście. W obszarze Engineering dzieci zapoznawały się z planami miast, ze strukturą ich budowy, konstruowały budowle (budynki, zabytki) i urządzenia występujące w mieście, projektowały ulice i chodniki, place zabaw itp., po których poruszały się ozoboty. W obszarze Art przedszkolaki układały tekst, który wygłaszał przewodnik, opracowywały i przygotowywały detale zdobnicze do swoich makiet. W obszarze Mathematics dzieci rozwijały myślenie i wyobraźnię przestrzenną dotyczącą następujących zagadnień: symetrii, parkietaży, podobieństwa figur, oraz ćwiczyły orientację przestrzenną.

\section{Prezentacja wyników obserwacji reakcji i działań dzieci}

\section{Wyniki obserwacji dzieci pod katem problemu 1}

Jedna grupa nie od razu zrozumiała idee wypełniania kartki papieru figurami i skupiła się na tworzeniu pięknych wzorów kwiatowych (fot. 1) (taką możliwość dawały różnokolorowe wielokąty). Po pytaniach prowadzącego, czy taki chodnik będzie funkcjonalny i zwróceniu uwagi na fakt, że miałby różne wysokości, jedna dziewczynka zauważyła, że trudno by było jej mamie na wysokich szpilkach chodzić po takim chodniku. Po tych uwagach dzieci w tej grupie zaczęły układać figury na kartce papieru, przykładając je wzdłuż boków. U niektórych osób zaobserwowano bardzo praktyczne podejście do rozwiązania problemu, tzn. dzieci wyszukiwały wielokąty, które do siebie pasują bez ,wielkich kombinacji”, co sprowadzało się do uzupełniania całej kartki jednym typem wielokąta, np. sześciokątem foremnym, kwadratem czy trójkątem, przy tym dzieci zwracały uwagę na kolor używanych figur.

Po wykonaniu zadania przedyskutowano z dziećmi reguły, które musi spełniać funkcjonalny chodnik. Następnie przeanalizowano z dziećmi ich prace pod tym kątem, uwzględniono również walory estetyczne utworzonych przez nich chodników. Zwrócono uwagę na regularności geometryczne, które powodują, że takie chodniki bardziej nam się podobają. 


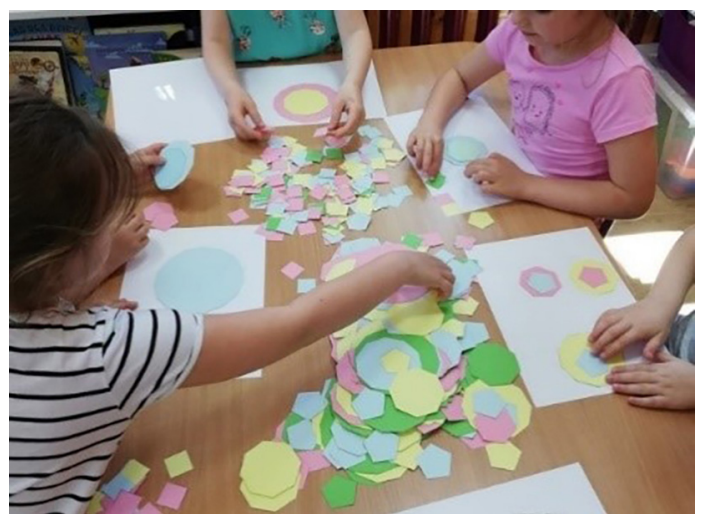

Fot. 1. Parkietaże

Źródło: archiwum autorki.

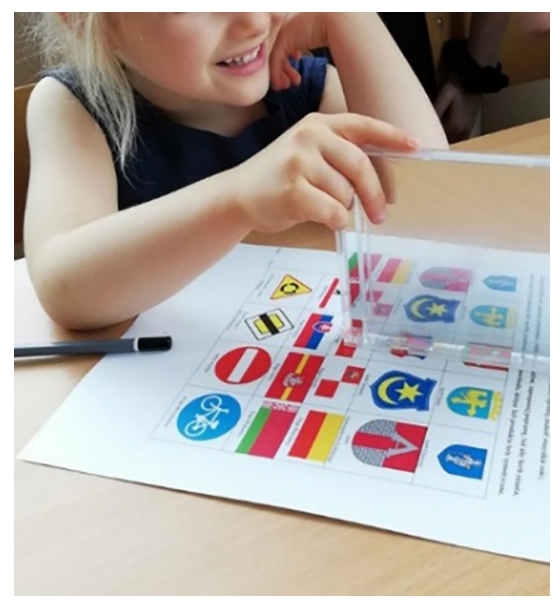

Fot. 2. Symetria elementów miasta

Źródło: archiwum autorki.

Wiele dzieci podjęło nieudane próby zapełnienia kartki papieru wielokątami „niepasującymi” do siebie (tzn. suma kątów przy ich połączeniu nie dawała $360^{\circ}$ ), komentowały to następująco: „te figury nie pasują do siebie, mają tu za dużo lub za mało [wskazując palcem złączenie tych figur], a chciałem złożyć taki wzorek [ruch w powietrzu palcem]”. Następnie wyjaśniono i pokazano dzieciom na przykładowym złożonym parkietażu, jak można byłoby takie chodniki zaplanować, kierując się np. z góry ustalonym kodem (układ liczb, które są liczbą poszczególnych boków figur, znajdujących się dookoła danego wierzchołka) na wierzchołek danego parkietażu-chodnika. Prowadzący czekał na propozycje dzieci dotyczące wyjaśnienia kodu-układu liczb do przedstawionego dzieciom parkietażu. Jedna dziewczynka zaproponowała wyjaśnienie i to ona następnie tłumaczyła dzieciom „o co chodzi”. Gdy każda grupa dostała swoje kody, ponownie proszono dzieci z każdej grupy o wyjaśnienie sposobu składania. Przez cały czas wykonywania przez dzieci parkietażu osoba dorosła dyskretnie ukierunkowywała pracę przedszkolaków. Obserwując pracujące dzieci, można było zauważyć, że dzieliły między sobą obowiązki, tzn. na osobę, która przynosiła na ławkę klocki o odpowiednim kształcie (np. gdy kod parkietażu był $(3,3,3,4,4)$, przynosiła klocki w kształcie trójkątów i kwadratów); na osoby, które składały poszczególne elementy parkietażu według podanego wzoru, i na osoby, które łączyły te elementy i starały się stworzyć wielki parkietaż. Po złożeniu przez grupy swoich parkietaży analizowano z dziećmi powstałe wzory.

\section{Wyniki obserwacji dzieci pod kątem problemu 2}

Większość dzieci w celu sprawdzenia, czy dany obiekt jest symetryczny, używało lusterek (fot. 2). 


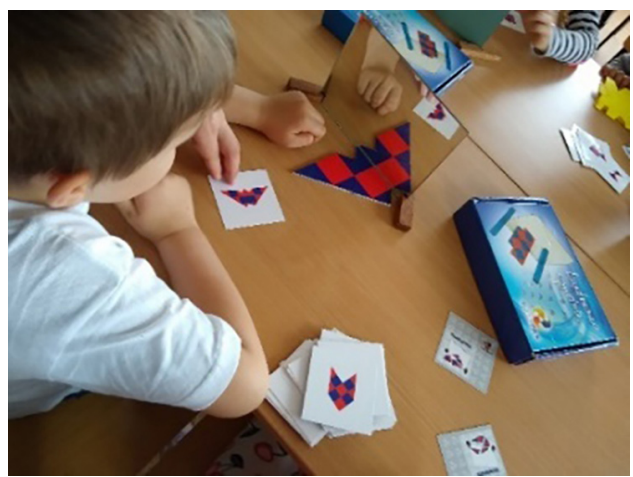

Fot. 3. Zestaw do składania figur z wykorzystaniem odbicia lustrzanego

Źródło: archiwum autorki.

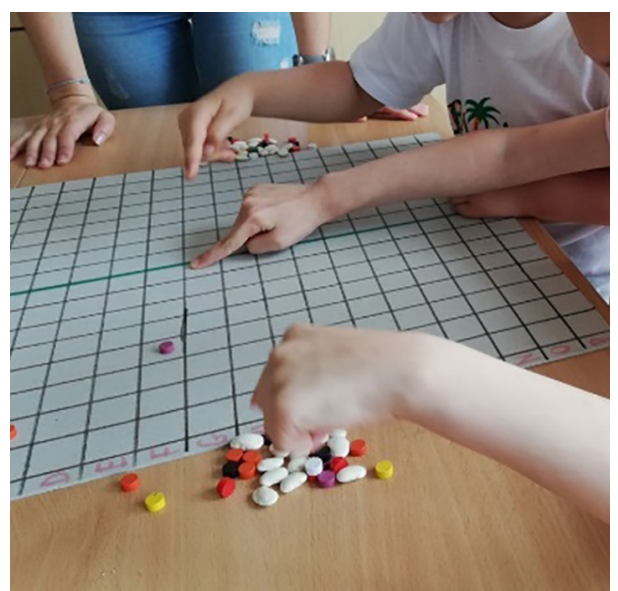

Fot. 4. Symetryczność w układzie

Źródło: archiwum autorki.

Wyjątkiem byli dwaj chłopcy, którzy w myśli próbowali sobie wyobrazić oś symetrii, a zamiast lusterka ustawiali $\mathrm{w}$ odpowiednim miejscu rękę. Jeden $\mathrm{z}$ chłopców wymyślił również sposób na łatwiejsze układanie obrazka z wykorzystaniem odbicia lustrzanego (fot. 3). Na początku ustawiał tak obrazek, aby było widać, gdzie ma być oś symetrii-lusterko, w późniejszym etapie swojej pracy część obrazka podkładał pod lusterko, pozostawiając tylko ten fragment, który musiał złożyć z dwóch klocków.

Podczas zaznaczania symetrycznych obiektów w kratkowanym układzie dzieci na początku pomagały sobie palcami (fot. 4). Później większość przedszkolaków chętnie układała elementy na planszy w taki sposób, aby były symetryczne względem dwóch osi bez wspomagania się rękoma i sprawdzania, czy jest dobrze.

\section{Wyniki obserwacji dzieci pod kątem problemu 3 i 4}

Odgadywanie i wskazywanie brył, które były rozwiązaniem poszczególnych zagadek, nie było trudne dla dzieci, problemem było jednak argumentowanie, dlaczego właśnie ta bryła spełnia warunki zagadki. Zazwyczaj dzieci odpowiadały: „bo tak to widzę”, „,bo tak jest” lub pokazywały na odpowiednim modelu bryły, że spełnia ona podane w zagadce warunki: „tak jest tutaj”. Dużym zaskoczeniem dla dzieci był fakt, że na stole znajdowało się więcej brył spełniających warunki zagadki.

Kolejnym zadaniem było złożenie bryły z podanych klocków magnetycznych, np. złożenie kostki z 6 kulek i 12 pałeczek magnetycznych lub piramidy z 4 kulek i 6 pałeczek magnetycznych. Niektóre dzieci, mimo podanej instrukcji, która mówiła o budowaniu budowli trójwymiarowych, układały figury płaskie. Obserwując dzieci podczas obliczania widocznych elementów sześcianu, graniastosłupa trójkątnego, ostrosłupa trójkątnego, 
można było zauważyć, że problemy z poprawnym policzeniem wierzchołków czy krawędzi danej bryły nie wynikały z nieumiejętności poprawnego liczenia, lecz z chaotycznego wskazywania i liczenia przez dzieci tych elementów. Osoby, które robiły to po kolei, tzn. np. najpierw obliczały wierzchołki z dolnej podstawy, potem z górnej lub krawędzie z dolnej podstawy, potem z boku i następnie z górnej, nie popełniały błędów.

Zabawa w detektywa nie sprawiła dzieciom większych problemów, manipulując bryłami, znajdowały odpowiednie rzuty na kartce papieru. Upominały się między sobą, gdy bryła wychodziła poza ślad lub była za mała w stosunku do śladu. Nie było również dla nich problemem, że któraś z brył nie pasowała do żadnego śladu lub że niektóre bryły „pozostawiły" na kartce papieru po dwa, a nawet trzy ślady (dla niektórych brył odrysowano podstawy i ściany boczne). Najwięcej trudności sprawiło dzieciom znalezienie różnych siatek sześcianu. Dzieci niepoprawnie łączyły klocki ze sobą, np. wierzchołkami nie bokami, nie trzymały się zasady, że pudełko sześcienne jest zbudowane z 6 ścianek (łączyły po 5 lub więcej niż 6 klocków), mimo że było to z nimi omawiane. Jeden z siedmioletnich chłopców poskładał z klocków kilka sześcianów, a następnie starał się w różny sposób je rozkładać, uzyskując różne siatki (znalazł 8). Zastosował metodę otrzymywania siatki, która była wykorzystywana podczas eksperymentu z dziećmi, polegającym na rozklejaniu prostopadłościennych pudełek.

\section{Wyniki obserwacji dzieci pod katem problemu 5 i 6}

Jedna grupa dzieci na całej makiecie wymalowała obiekty, nawet bardzo szczegółowe pod względem estetyki i kolorystyki, jednak nie były one przestrzenne ani nie były rzutami na płaszczyznę, były to dwuwymiarowe obrazki obiektów trójwymiarowych. Pozostałe dzieci dobrze sobie poradziły z tą aktywnością. Dzieci zachowały kształt wykonanych budowli, niektóre wykorzystały gotowe pudełka, na których wymalowały charakterystyczne elementy danej budowli lub jej nazwy lub które okleiły.

Dzieci ze wszystkich grup najpierw rysowały na makiecie trasę ozobota, a następnie sprawdzały, czy robot dobrze się porusza. Taka metoda powodowała jednak, że niezbędne były poprawki, które nanoszono na makietę, doklejając kolejne białe kartki z nową trasą (fot. 5,6). Dzieci często myliły się w określaniu stron lewa-prawa i kierunku poruszania się robotem. W wielu przypadkach rzeczywiste poruszanie się robota bardzo odbiegało od wcześniejszej zaplanowanej przez grupę trasy. Niektórym dzieciom pomagała wskazówka: wyobraź sobie, że ty jesteś tym ozobotem, oraz to, że osoba badająca siadała naprzeciwko dzieci i mówiła: teraz ja jestem tym ozobotem. Dla dzieci było to bodźcem do wykonania odpowiedniego przesunięcia w myśli. Podczas obserwacji zajęć zadawano dzieciom pytania: co zobaczy wasz ozobot dookoła siebie, gdy stanie na tym skrzyżowaniu; opisz, jak dojść z tego placu do przystanku itp.; opowiedz, co widzi ozobot po swojej prawej/lewej stronie, jadąc tą ulicą z... do..., a co, jak będzie wracał; czy mijane przez niego obiekty będą również znajdować się po jego prawej/lewej stronie; jaka będzie kolejność ich mijania, czy taka sama jak wcześniej; co powie ozobot przejeżdżający ulicami miasta; po której swojej stronie będzie mijał: muzeum, sklep, kościół itp., a po której gdy będzie jechać z powrotem. 

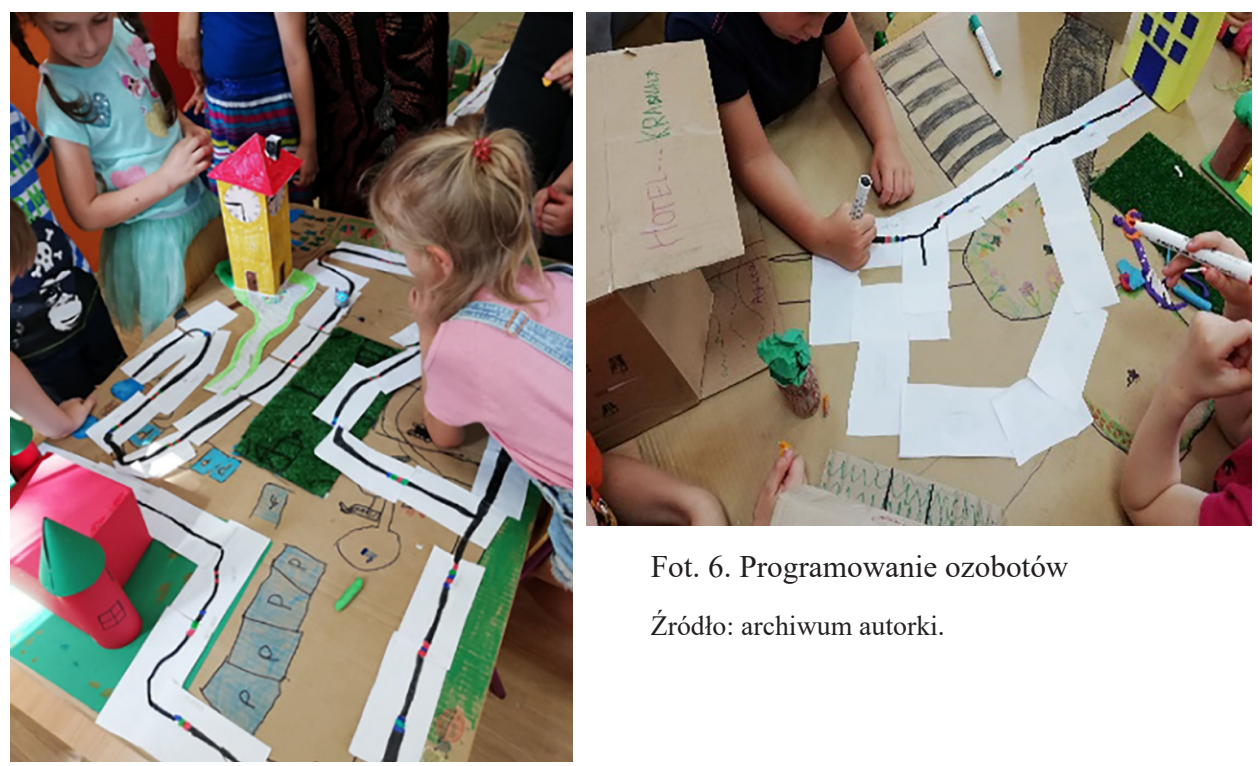

Fot. 6. Programowanie ozobotów

Źródło: archiwum autorki.

Fot. 5. Makieta

Źródło: archiwum autorki.

\section{Wnioski z przeprowadzonych badań}

Chociaż w podstawie programowej dla młodszych dzieci geometria nie jest wyraźnie obecna, dzieci spotykają się z zagadnieniami geometrycznymi w codziennym życiu. Układając budowle z klocków czy lepiąc figurki z plasteliny, dzieci poruszają się w świecie trójwymiarowym. Potrafią sklejać modele przestrzenne. Na podstawie ich prac można odnieść wrażenie, że bardzo dobrze radzą sobie w trzecim wymiarze, potrafią się w nim poruszać, znają obowiązujące w nim reguły i zależności.

Obserwowane podczas zajęć przedszkolaki samodzielnie dochodziły do praktycznych wniosków dotyczących budowy chodników. Mówiły lub w większości pokazywały, w jaki sposób należy przykładać jeden kafelek do drugiego, aby chodnik był funkcjonalny, żeby nie było w nim żadnych dziur ani różnych poziomów wielkości.

W większości wypowiedzi dzieciom brakowało słów i wykorzystywały podczas swojej argumentacji mimikę twarzy lub wskazywanie palcem na konkretny obiekt (np. podczas zagadek). Połowa grupy przedszkolnej nie radziła sobie bez dyskretnych podpowiedzi ze składaniem brył z wykorzystaniem klocków magnetycznych (większość osób składała je na płaszczyźnie) czy z szukaniem siatek sześcianu. Dzieci nie miały problemu ze zrozumieniem sposobu poruszania się robota i bardzo chętnie próbowały go ,,programować", żywiołowo reagując, gdy poruszał się on nie tak, jak chciały. Wykorzystanie ozobotów podczas tych zajęć z jednej strony je uatrakcyjniło, z drugiej zaś spowodowało, że 
pojawiły się ruch/dynamika, które w zdecydowanie lepszy sposób pokazały prezentowane zagadnienia geometryczne. Dzieci, malując odpowiednie kody na makiecie, umożliwiały robotowi przejście drogi w zaplanowany przez nich sposób, dało to również możliwość wprowadzenia wielu poprawek bez poczucia, że zrobiły coś źle, aby uzyskać zamierzony efekt. Po każdych zajęciach matematycznych ${ }^{1}$ prowadzący otrzymywał informację od nauczycielek, że po skończonych zajęciach niektóre dzieci dalej zajmowały się prezentowanymi problemami i zadawały mnóstwo pytań. Po zajęciach dotyczących parkietaży dzieci, bawiąc się dalej klockami Reko, w większości odwzorowywały parkietaże, które były omawiane i tworzone na zajęciach. Jeden chłopiec wymyślał swoje kody i na ich podstawie starał się składać swój chodnik (jednak po wielu nieudanych próbach rezygnował $\mathrm{z}$ działania ${ }^{2}$ ). Po zajęciach dotyczących symetrii dzieci tworzyły własne symetryczne prace z makaronów, fasolek, chrupek, drażetek itp. Po zajęciach dotyczących brył niektóre dzieci wycinały siatki brył i sklejały graniastosłupy i ostrosłupy. Chętnie bawiły się klockami magnetycznymi, wymyślając sobie nawzajem problemy, które były podobne do prezentowanych na zajęciach. Po zajęciach dotyczących robotów jeden chłopiec stworzył na kartce swój plan poruszania się ozobota, uwzględniając wszystkie z możliwych dla tego robota opcji, następnie zainteresowanym dzieciom prezentował i opowiadał, jak porusza się po niej ,wirtualny” robot.

Przedstawione w artykule wyniki obserwacji reakcji dzieci są jedynie wycinkiem planowanych badań ${ }^{3}$.Zdaniem autorki ich tematyka nie została w pełni wyczerpana i powinna być w przyszłości uzupełniona i poddana dalszym analizom.

\section{Podsumowanie}

Prezentowany projekt stworzył przedszkolakom dobrą okazję do zdobywania doświadczeń związanych z zagadnieniami geometrycznymi, co zgadza się z koncepcją metodyczną zaproponowaną przez Semadeniego, który mówi, że najpierw w umyśle dziecka pojęcie pojawia się jako proces, jako „rzecz do zrobienia”, a dopiero później jako obiekt, abstrakcyjny twór (za: Bugajska-Jaszczołt, Drygła 2006: 155). Ponadto STEAM-owe zajęcia dały dzieciom przestrzeń do twórczej pracy, do ekspresji artystycznej, projektowania i realizacji własnych pomysłów, dochodzenia do celu własną lub uzgodnioną w grupie drogą (Trojańska 2018: 10). Ta koncepcja uczenia się pozwala na wyrażenie wiedzy geometrycznej i jej zakodowanie co najmniej dwoma sposobami - wizualnym i dotykowym. Pomaga powiązać każdy kształt ze zbiorem obiektów ze świata realnego. Umożliwia in-

\footnotetext{
1 Na czas trwania projektu prowadzący wypożyczył dzieciom: klocki Reko i magnetyczne; siatki papierowe brył, aby miały możliwość dalszej nimi manipulacji.

2 Nauczycielki w przedszkolu nie umiały mu wytłumaczyć, dlaczego z innych układów liczb nie można zbudować parkietażu, który by miał jednolity układ przy każdym wierzchołku.

3 W latach 2020 i 2021 planowano powtórzenie tych badań w grupie przedszkolnej i wśród dzieci z klas I-III. Niestety sytuacja w kraju to uniemożliwiła. Badania planuje się późniejszym czasie.
} 
tegrację i wykorzystanie wiedzy i narzędzi matematycznych. Daje okazję do aktywności geometrycznych, takich jak: obserwowanie, manipulacja, badanie, kreowanie, werbalizowanie, konstruowanie (Hejny 1997: 26) i czerpania z nich radości (Mączka 2016: 85). Może również inspirować i zachęcać do poszukiwania nowych rozwiązań. Tworzy atmosferę bezpieczeństwa i akceptacji, w której popełnienie błędu traktowane jest jako naturalny, wręcz nieodzowny krok w poszukiwaniu skutecznego rozwiązania problemu, a nie jako przejaw niewiedzy. Pokazuje, że w „grupie siła” dzięki uwzględnieniu różnych talentów, zainteresowań i indywidualnych predyspozycji każdego członka grupy.

\section{Literatura}

Bilewicz-Kuźnia B. (2014), Edukacja geometryczna dzieci. Lublin, Wydawnictwo Uniwersytetu Marii Curie-Skłodowskiej.

Bojarska-Sokołowska A. (2015), Edukacja matematyczna na tle innych dziedzin i form działalności dziecięcych uniwersytetów na przykładzie Uniwersytetu Dzieci w Olsztynie. Olsztyn, Wydawnictwo Uniwersytetu Warmińsko-Mazurskiego w Olsztynie.

Bojarska-Sokołowska A. (2019), Pozaszkolne formy edukacji matematycznej. Popularyzacja matematyki, interaktywność w kształceniu, kultura matematyczna. Olsztyn, Wydawnictwo Uniwersytetu Warmińsko-Mazurskiego w Olsztynie.

Bruner J. (1978), Poza dostarczone informacje. Warszawa, PWN.

Bugajska-Jaszczołt B., Drygała D. (2006), Jak uczymy przyszłych nauczycieli algebry liniowej? W: M. Czajkowska, G. Treliński (red.), Kształcenie matematyczne. Tendencje, badania, propozycje dydaktyczne. Kielce, Wydawnictwo Akademii Świętokrzyskiej.

Czajkowska M., Bugajska-Jaszczołt B. (2018), Umiejętności geometryczne trzecioklasistów w świetle wyników badań. „Problemy Wczesnej Edukacji”, 40(1).

Filip J., Rams T. (2000), Dziecko w świecie matematyki. Kraków, Oficyna Wydawnicza „Impuls”.

Gruszczyk-Kolczyńska E. (2015), Dziecięca matematyka - dwadzieścia lat później. Kraków, Wydawnictwo Bliżej Przedszkola.

Gruszczyk-Kolczyńska E. (2016), O kryzysie edukacji matematycznej dzieci. Rozpaczliwe wołanie o działania naprawcze. „Matematyczna Edukacja Dzieci”, 1.

Hejny M. (1997), Rozwój wiedzy matematycznej. „Dydaktyka Matematyki”, 19.

Komeński J.A. (1956), Wielka Dydaktyka. Wrocław, Wydawnictwo PAN.

Mączka M. (2016), Pierwsze spotkanie uczniów z geometria - jak to robia Japończycy? „Matematyczna Edukacja Dzieci”, 1.

Nowecki B. (1988), Nauczanie początkowe matematyki. Podręcznik dla nauczyciela. T. 4. Warszawa, WSiP.

Plebańska M. (2018), STEAM - edukacja przyszłości. „Meritum”, 51(4).

Plebańska M., Trojańska K. (2018), STEAM-owe Lekcje (EPUB). Warszawa, elitera.

Pytlak M. (2014), Wprowadzenie uczniów klasy III szkoły podstawowej w świat geometrii trójwymiarowej. W: H. Kąkol (red.), Współczesne problemy nauczania matematyki. Bielsko-Biała, Wydawca Koło SNM Forum Dydaktyków Matematyki. 
Tocki J. (2006), Struktura procesu kształcenia matematycznego. Cz. 1. Rzeszów, Wydawnictwo Uniwersytetu Rzeszowskiego.

Trojańska K. (2018), STEAM-owe lekcje. „Meritum”, 51(4).

Semadeni Z. (2018), Porównanie poziomów rozwoju pojęć geometrycznych u uczniów Hejnego z poziomami van Hielów. „Journal of Modern Science”, 37(2).

Semadeni Z., Gruszczyk-Kolczyńska G., Treliński G., Bugajska-Jaszczołt B., Czajkowska M. (2015), Matematyczna edukacja wczesnoszkolna. Teoria i praktyka. Kielce, Wydawnictwo Pedagogiczne ZNP.

Swoboda E. (2006), Przestrzeń, regularności geometryczne i ksztalty w uczeniu się i nauczaniu dzieci. Rzeszów, Wydawnictwo Uniwersytetu Rzeszowskiego.

van Hiele P.M. (2003), Podobieństwa i różnice między teoria uczenia się i nauczania Skempa a poziomami myślenia van Hielego. „Dydaktyka Matematyki”, 19.

\section{Akty prawne}

Rozporządzenie Ministra Edukacji Narodowej z dnia 14 lutego 2017 r. w sprawie podstawy programowej wychowania przedszkolnego oraz podstawy programowej kształcenia ogólnego dla szkoły podstawowej, w tym dla uczniów z niepełnosprawnością intelektualną w stopniu umiarkowanym lub znacznym, kształcenia ogólnego dla branżowej szkoły I stopnia, kształcenia ogólnego dla szkoły specjalnej przysposabiającej do pracy oraz kształcenia ogólnego dla szkoły policealnej (Dz. U. z 2017 r., poz. 356, ze zm.). 